\title{
Spatial and temporal variations of stygobite Amphipod populations in interstitial aquatic habitats of karst / floodplain interfaces in France and Morocco
}

\author{
J. Mathieu 1 \\ K. Essafi ${ }^{2}$ \\ H. Chergui ${ }^{2}$
}

Keywords : stygobite Amphipods, population dynamics, interface, France, Morocco.

Artificial substrates buried in stream sediments at the karst/floodplain interface were used to examine the spatial and temporal variations of the stygobite Amphipods Niphargus rhenorhodanensis (two stations in France) and Pseudoniphargus sp (one station in Morocco) populations. One station («Verna», France) was supplied by karst water. The other two stations («Pissoir», France and «Grotte du Chameau», Morocco) were supplied by both karst and surface waters. The dynamics of the populations was found to depend on several interacting factors: spates, geological characteristics, location of the sediment in relation to karstic water supplies and depth within the sediment.

Variations spatiales et temporelles de populations aquatiques interstitielles d'Amphipodes stygobies français et marocains à l'interface karst / plaine alluviale

Mots-clés : Amphipodes stygobies, dynamique population, interface, France, Maroc.

Des substrats artificiels enfoncés dans les sédiments de cours d'eau situés à l'interface karst/plaine alluviale ont été utilisés pour étudier la dynamique de populations d'Amphipodes stygobies: Niphargus rhenorhodanensis (deux stations en France) et Pseudoniphargus sp. (une station au Maroc). L'une des stations («Verna», France) est alimentée uniquement par de l'eau karstique. Les deux autres («Pissoir», France et «grotte du Chameau», Maroc) sont alimentées à la fois par de l'eau karstique et de l'eau superficielle. La dynamique des populations dépend de plusieurs facteurs interagissant: les crues, les caractéristiques géologiques des sorties d'eau, la place des sédiments par rapport aux sorties d'eau karstique, et enfin la profondeur dans les sédiments.

\section{Introduction}

The dynamics of superficial and underground faunal populations mainly depend on the piezometric level and are related to the different phases of the hydrological cycle of superficial and subterranean flow. Works concerning the structure of interstitial Amphipod populations are numerous in France (for review, see Es-

\footnotetext{
1. Université Claude Bernard Lyon 1, ESA CNRS 5023 Ecologie des eaux douces et des grands fleuves, 43 bd du 11 novembre 1918 , F-69622 Villeurbanne cedex, France.

E-mail : mathieu@biomserv.univ-lyon1.fr

2. Université Sidi Mohamed Ben Abdellah, Faculté des Sciences Dhar El Mehraz, laboratoire d'hydrobiologie et écologie générale, B.P. 1796 Fès-Atlas, Morocco.
}

safi 1990, Mathieu et al. 1994), but they are almost non-existent in Morocco (Essafi et al. 1995). To test different models of stygobite Amphipod populations living in interstitial habitats at the karst/floodplain interface, it was necessary to compare data obtained in different areas under different climates. Data obtained on such systems were located in the French karstic Jura (Essafi 1990, Mathieu \& Essafi 1990 ; Mathieu et al. 1992, Mathieu et al. 1994) and in the Béni-Snassen karstic system (Essafi et al. 1995), and concern temperate and mediterranean areas. The present paper focuses on the understanding of major processes that determine the population structures and their changes by using the spatial distribution of two stygobite Amphipods, Niphargus rhenorhodanensis in France, and Pseudoniphargus sp in Morocco. 


\section{Material and methods}

\subsection{Study sites}

- In France

«Verna» station (département de l'Isère) (I.G.N. map 1/25000 : Montluel $n^{\circ} 7-8$, Lambert coordinates : $\mathrm{x}=829.26, \mathrm{y}=91.06, \mathrm{z}=275.00$ ) is a spring which supplies a karst stream flowing down to the Rhône River. This site, which is part of a karst unit including 6 other springs (Fourneaux \& Durr 1983, Drouin \& Bigeard 1987), is located at the base-level of the massif. Three artificial substrates were buried in the sediments, which are mostly limestone gravel and clay (Fig. 1 A). One was located in the cave entrance («cave») the other two were $50 \mathrm{~m}$ downstream in the alluvial plain, one on the right bank and the other on the left bank («right», «left») (Mathieu \& Essafi-Chergui 1990).

«Pissoir» station (département de l'Ain) (I.G.N. map $1 / 25000$ : St Rambert en Bugey $n^{\circ} 5-6$, Lambert coordinates : $\mathrm{x}=838.47 ; \mathrm{y}=106.69 ; \mathrm{z}=310.00$ ) is a more complicated hydrological system. It is an emergence which drains the whole massif of Dorvan (Gibert 1986). This massif has many secondary springs. «Pissoir» spring acts as an over-flow level (the sediment of the floodplain is thick under the spring) and partly supplies a small surface stream (the Bief Ravinet, which flows into the Albarine River, which itself flows into the Ain River) (Gibert 1986, Gibert et al. 1983). The sediments were also mostly limestone gravel and clay. Artificial substrates were placed on both sides of the stream (Bief Ravinet) (Fig. 1 B). The first sampling sites (Fig. 1 B : «P I Right» and «P I Left») were located upstream and only supplied by surface water. The intermediate sites (near secondary springs) ( $\mathrm{P}$ II Right» and «P II Left») were located approximately 50 metres upstream from the third sites («P III Right» and «P III Left»), which were near the main outflow of the karst system. Artificial substrates located on the left bank of the river in the last two sampling sites were mainly supplied by karst water and those located on the right bank were supplied by both karst and surface water.

\section{- In Morocco}

The exsurgence of the «grotte du Chameau» $(X=$ $778.25 ; Y=474.85 ; Z=500$ ), which partly supplies Oued Zeghzel, is located near the Northeastern extremity of Morocco. This part of the Beni Snassen Mountain Range is a karstic and highly permeable system. The rainfall causes a watertable to flow north and feeds the three main permanent springs of Oued Zeghzel (Stretta 1950, Carlier 1971), including Aïn Bourbah, in the "grotte du chameau», which contributes most of the discharge of Oued Ferrouj and the lower Zeghzel.

The right bank of the Ferrouj skirts the outlet of the cave. Stations 1, 4 and 5 are supplied by surface water ; station 3 is supplied by both surface and groundwater and station 2 is supplied by groundwater (Fig. 2-2 A).

The lower Zeghzel is located about $6 \mathrm{~km}$ downstream from the cave. Summer discharge is low, owing to the derivation of water for irrigation upstream. Station 7 is supplied by surface water whereas stations 6 , 8 and 9 are supplied by water from karstic springs along the right bank of the stream (Fig. 2-2 B).

\subsection{Artificial substrates}

Each artificial substrate (Fig. 1 C) consisted of a cylinder $10 \mathrm{~cm}$ in diameter and $50 \mathrm{~cm}$ long in which $8 \mathrm{~mm}$ holes had been drilled. Each cylinder was buried $50 \mathrm{~cm}$ deep in the stream bank and contained five baskets one above the other, made of $6 \mathrm{~mm}$ mesh (diameter : $10 \mathrm{~cm}$; height : $10 \mathrm{~cm}$ ) (Mathieu \& Essafi-Chergui 1990). The baskets were filled with the local sediment that had been carefully cleaned and dried. This sediment was mainly angular gravel, and fine sand $(<1 \mathrm{~mm})$ which filled the spaces between the gravel.

\subsection{Sample collection}

The artificial substrates were exposed for about one month, the estimated duration needed to obtain the equilibrium between organic matter and fauna supply in the substrate (Mathieu et al., 1994).

In France, they were recovered between 19 November 1987 and 23 June 1989 at the «Verna» station, and between 28 November 1987 and 25 May 1989 at the «Pissoir» station (Fig. 3).

In Morocco, they were collected and replaced monthly from September 1991 to October 1992 (except in July 1992) : $(21 / 09 / 91-19 / 10 / 91-20 / 11 / 91$ 23/12/91 - 25/01/92 - 28/02/92 - 28/03/92 - 30/04/92 29/05/92 - 26/06/92 - 07/08/92 - 11/09/92 - 15/10/92) (Fig. 3).

In the laboratory, all the material from each basket was washed through a $150 \mu \mathrm{m}$ mesh sieve. After removal of most sand and gravel, animals were picked from the residue, composed of sand and particulate organic matter, and preserved in $5 \%$ Rose Bengal formalin.

\section{Results}

\section{- In France}

The changes in the numbers of Niphargus rhenorhodanensis in the two French sites indicate the existence of two distinct periods separated by a spate which oc- 

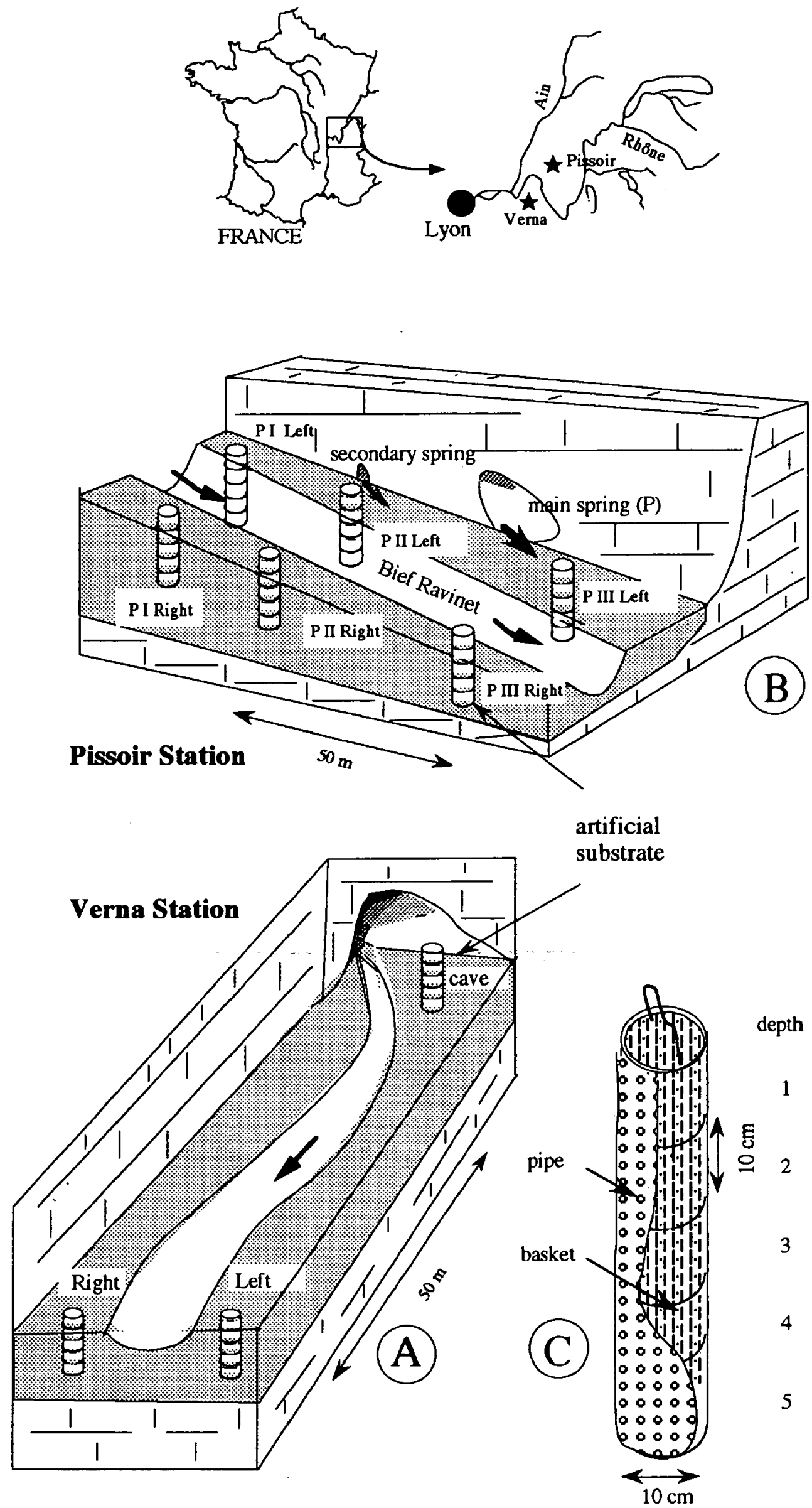

Fig. 1. Location of artificial substrates in «Verna» (A) and «Pissoir» (B) stations (French Jura). The upper «Pissoir» station (P I) did not contain Niphargus rhenorhodanensis, and was not considered in this study. For the same reason, right and left artificial substrates of the «Verna» station were eliminated from this study. Dashed areas represent the sediment on limestone. C : design of an artificial substrate (adapted from Essafi et al. 1992, 1995).

Fig. 1. Localisation des substrats artificiels dans les stations de «Verna» (A) et du «Pissoir» (B) (Jura français). La station amont du «Pissoir» (P I) ne contenant pas de Niphargus rhenorhodanensis n'a pas été prise en compte dans cette étude. Pour la même raison, les substrats artificiels droit et gauche de «Verna» ont été éliminés de cette étude. C : schéma d'un substrat artificiel (d'après Essafi et al. 1992, 1995). 


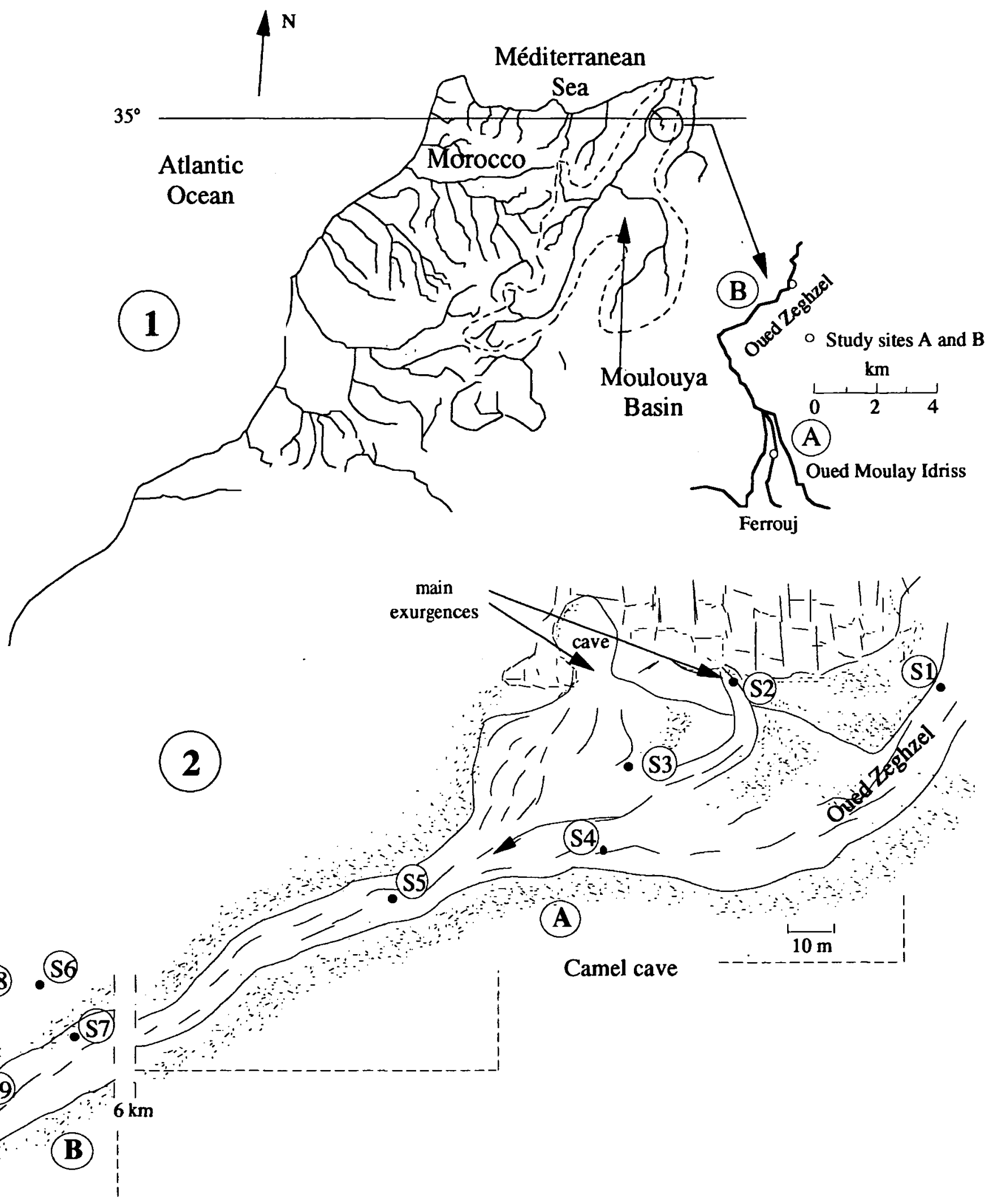

Lower Zegzhel

Fig. 2.1 : Location of the alluvial floodplain of the Moulouya and its tributary Oued Zeghzel in Morocco. $2:$ the 9 sampling sites : A : «Grotte du Chameau», and B : lower Zeghzel (adapted from Essafi et al. 1995).

Fig. 2.1 : Localisation de la plaine alluviale de la Moulouya et de son affluent l'Oued Zeghzel au Maroc. 2 : Les 9 stations de prélèvement : A : «Grotte du Chameau», B : le bas Zeghzel (d'après Essafi et al. 1995). 


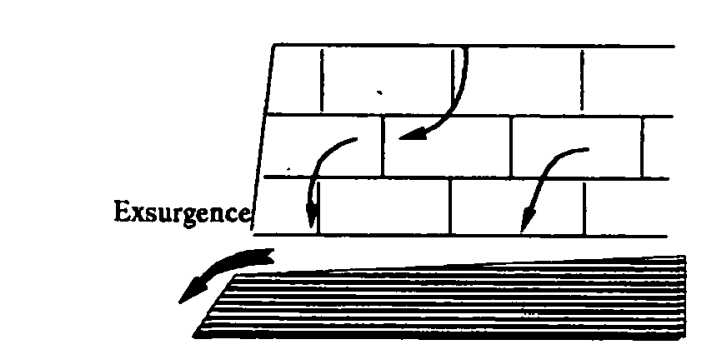

Base level exsurgence Impermeable layer

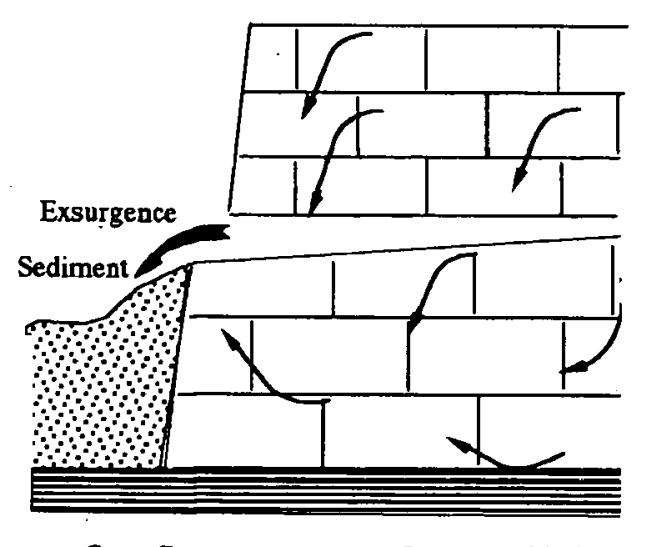

Over flow exsurgence Impermeable layer
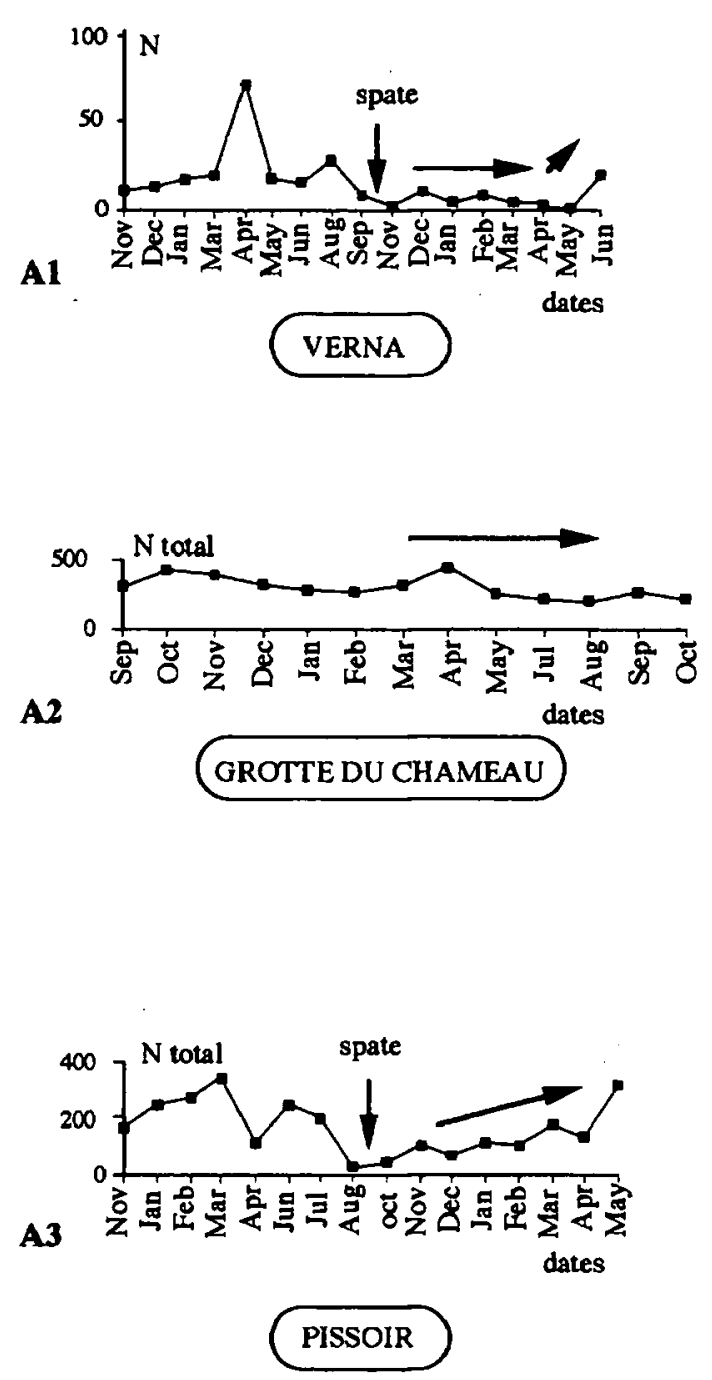
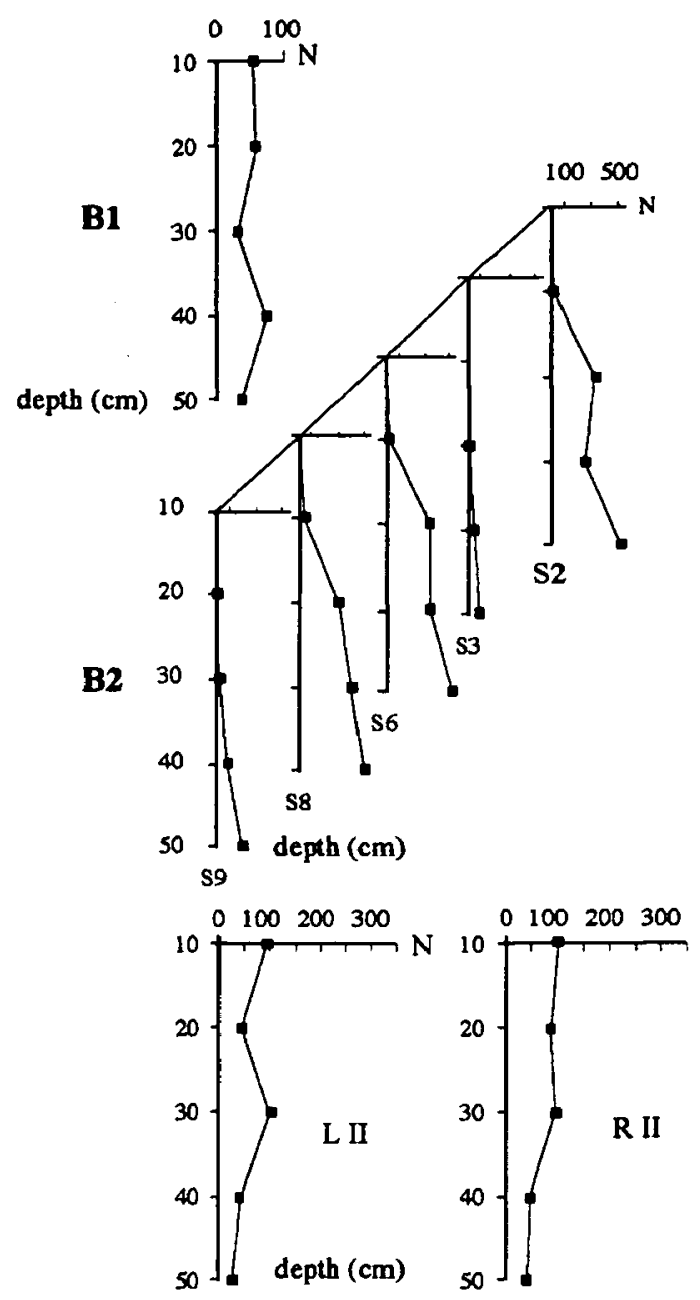

$\mathbf{B 3}$

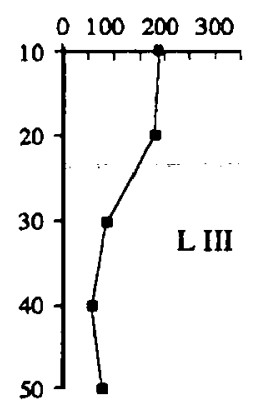

Fig. 3. A1, A2, A3 : numbers of individuals (Niphargus rhenorhodanensis in France and Pseudoniphargus sp. in Morocco) sampled during the studies at the 3 stations. Numbers are the sum of all sampling sites by date. B1, B2, B3 : numbers of individuals at the different depths in the sediment ( $N$. rhenorhodanensis in France and Pseudoniphargus sp. in Morocco). Numbers are the sum of all sampling dates by depth. S2 to S9 : sampling sites in the «grotte du Chameau» and Lower Zeghzel. L and R : left and right banks at the «Pissoir» station. II and III : $2 \mathrm{~d}$ and 3rd sites at the «Pissoir» station.

Fig. 3. A1, A2, A3 : nombre d'individus (Niphargus rhenorhodanensis en France et Pseudoniphargus sp. au Maroc) récoltés dans les 3 sites Les nombres correspondent aux sommes du nombre d'individus de toutes les stations par date. B1, B2, B3 : nombre d'individus récoltés aux différentes profondeurs dans les sédiments (Niphargus rhenorhodanensis en France et Pseudoniphargus sp. au Maroc). Les nombres correspondent aux sommes du nombre d'individus de toutes les dates par profondeur. S2 à S9: stations de prélèvements de la «grotte du Chameau» et du bas Zeghzel. L et $\mathrm{R}$ : rives gauche et droite au site du «Pissoir». II et III : $2^{\text {ème }}$ et $3^{\text {ème }}$ stations au site du «Pissoir».

curred on $12 / 10 / 1988$. The first period showed numerous individuals whereas the second presented few individuals. However, these changes were different between the two sites.

In «Verna», only the artificial substrate placed in the cave contained N.rhenorhodanensis. The number of individuals of the first period was three times higher than that of the second period, and it was necessary to wait six months before obtaining the number of the first period (Fig. $3 \mathrm{~A} 1$ ). The mean values between the two periods were significant $(t=8.5,15 \mathrm{DF}, p<0.01)$. Individual numbers were constant with depth (Fig. 3 B1).

In the «Pissoir» case, the first site (PI L, PI R) did not contain $N$. rhenorhodanensis. For the two other sites, 
an average of $51 \pm 17$ individuals was found before the spate. After the spate, this number was only $28 \pm 5$. Numbers increased from autumn to spring and then decreased until the low water of August of the first period (Fig. 3 A3). The second period showed a regular increase of $N$. rhenorhodanensis numbers. The mean values between the two periods were significant $(t=5.22$, $14 \mathrm{DF}, p<0.01$ ). The stations located at the outlet (L II and L III) were less inhabited than those located on the bank opposite the outlet (R II and R III) $(p<0.05)$. The number of individuals generally decreased with depth at each site in this station. The numbers of individuals were higher in the highest baskets, especially in the site III, where the data were significant between the highest and the lowest baskets ( $p<0.05)$ (Fig. 3 B3). This difference was less important at the site II. Intermediate values $(20,30,40 \mathrm{~cm}$ were not different between them.

\section{- In Morocco}

Pseudoniphargus sp. were found only in the stations supplied by karst water and their global numbers remained almost constant during the study (Fig. 3 A2). In contrast with the French «Pissoir», when the sites are supplied with karst water, individual numbers increased with depth and the difference between the highest and the lowest baskets were significant $(p<0.05)$ (Fig. 3 B2).

\section{Discussion and conclusion}

By using artificial substrates buried in the sediment, it was possible to observe the distribution in space and time of stygobite Amphipod populations living either in temperate or in warm Mediterranean climates.

It has been stated that the presence and the number of these Amphipods depends on the location of the sediments in relation with the outflows (Essafi et al. 1992, 1995). They were almost found only in stations supplied by karstic water. This result indicates that the sediments can be occupied by stygobite species only when they are connected with karst water, which brings them out from karstic systems. This situation occurred as well in France as in Morocco.

The comparison of the three sites showed that the occupation of the sediments by the stygobite Amphipods results from the hydrological conditions (Angelier 1953, Mathieu et al v1984, 1987) and particularily from the presence or absence of spates. However, in this comparison, each example appears to be original compared to the other two, and it is difficult to give a general explanation. The relative homogeneity of the distribution with depth at the «Verna» station and the different gradients obtained at the «Pissoir» and the «Grotte du Chameau» stations are certainly linked to the hydrologic regimes which differ in their details. The distribution of Niphargus rhenorhodanensis at the «Pissoir» station showing a decrease with depth is directly linked to the discharge of water flowing out from the karstic system. The case of Pseudoniphargus $s p$. is different. The numbers of individuals varied little during the observations and no individuals were found in the first $\mathrm{cm}$ of the sediments (Essafi et al 1995). This difference could be the result of the persisting high discharge at the outflow and of deep colonization in the sediments that prevented the drift of the population downstream.

The influence of spates on invertebrate populations has been well documented (see Resh et al. 1988). The structure of populations of the stygobite species studied varies according to the geological structure of the emergence. If the emergence is situated at the base-level, then the individuals are to be found mainly inside the karst, but they are not abundant and very few are collected outside the karst (Essafi et al. 1992). The shallow sediments prevent the development of interstitial populations and the animals which leave the karst seem to be placed immediately in the trophic cycle of the river. They usually have to face problems of competition with other Amphipods, that are often present in large numbers, and may also be predators. In this case, it seems highly unlikely that the population will be able to recover after a spate (Mathieu \& Essafi 1990, Essafi et al. 1992). The situation is different when the emergence occurs as an overflow. When refuges exist in the sediment and where the supply of individuals from the karst is high, population numbers remain relatively high after a spate and recolonization is immediate in spite of the total drying out of the alluvial sediment during summer.

\section{Acknowledgements}

The authors thanks Dr E. Pattée for his assistance in editing the text. Thanks also to the anonymous rewiewer who permited to improve the manuscript.

\section{References}

Angelier E. - 1953. Recherches écologiques et biogéographiques sur la faune des sables submergés. Arch. Zool. Exp. et Géné., 90 : 37-161.

Carlier P. 1971. — La chaîne des Benni-Bou-Yahi Benni Snassen et la plaine de Triffa. Notes Mém. Serv. Géol. Maroc n' 231. Ressources en eau du Maroc, Tome $1: 291-315$

Drouin P. \& Bigeard P. 1987. - La fontaine Saint-Joseph (Verna, Isère). Spelunca, $27:$ 12-17. 
Essafi K. 1990. - Structure et transfert des peuplements aquatiques souterrains à l'interface karst-plaine alluviale. Thèse Doct. Univ. Lyon I, $102 \mathrm{p}$.

Essafi K., Mathieu J. \& Beffy J. L. 1992. - Spatial and temporal variations of Niphargus populations in interstitial aquatic habitat at the karst/floodplain interface. Regulated Rivers : Research \& Management, 7 : 83-92.

Essafi K., Mathieu J. \& Pattee E. 1995. - Changes in the structure of subterranean aquatic populations of the karstic system of Oued Zeghzel (Eastern Morocco). Arch. Hydrobiol., 135 : 195-208.

Fourneaux J. C. \& Durr F. 1983. - Influence d'une variation du niveau de base sur un karst tabulaire le massif d'Annoisin-Chatelans, dans l'Ile Crémieu (Isère). C. R. 108ème Cong. Nat. Soc. Sav., $1:$ 301-309.

Gibert J. 1986. - Ecologie d'un système karstique jurassien. Hydrogéologie, dérive animale, transit de matière, dynamique de la population de Niphargus (Crustacé Amphipode). Mém. Biospéol., $13: 1-379$.

Gibert J., Laurent R. \& Maire R. 1983. - Carte hydrogéomorphologique au 1/10 000 du karst de Dorvan (Jura méridional, Ain, France). Présentation et principales données sur l'hydrogéologie et l'hydrochimie de ce karst. Karstologia, $2: 33-40$.

Mathieu J., Debouzie D. \& Martin D. 1987. - Influence des conditions hydrologiques sur la dynamique d'une population phréatique de Niphargus rhenorhodanensis (Amphipode souterrain). Vie et Milieu, 37 : 193-200.
Mathieu J. \& Essafi K. 1990. - Le peuplement aquatique interstitiel à l'interface karst / plaine alluviale, 1. Cas d'une alimentation en eau essentiellement karstique. Mém. Biospéol., 17 : 113-122.

Mathieu J. \& Essafi-Chergui K. 1990. - Changes in abundance of interstitial populations of Niphargus (stygobiont Amphipod) at the karst/floodplain interface. C. R. Acad. Sci. Paris, 312 : 489-494.

Mathieu J., Essafi-Chergui K \& Culver D. C. 1992. - Variations in the structure of stygobiont crustacean populations (Niphargus rhenorhodanensis and Proasellus valdensis) within the sediment of a karst outflow. Hydrobiologia, $243: 41-49$.

Mathieu J., Essafi-Chergui K \& Jeannerod F. (1994) - A gradient of interstitial Niphargus rhenorhodanensis populations in two karst/floodplain transition zones of the French Jura. Hydrobiologia, 286 : 129-137.

Mathieu J., Martin D. \& Huissoud P. 1984. — Influence des conditions hydrologiques sur l'évolution de la structure spatiale et la démographie d'une population de l'Amphipode Niphargus rhenorhodanensis. - Premiers résultats. Mém. Biospéol., 11 : 27-36.

Resh V.H., Brown A.V., Covich A.P., Gurtz M.E.LH.W., Minshall G.W., Reice S.R., Sheldon A.L., Wallace J.B. \& Wissmar R.C. 1988. - The role of disturbance in stream ecology. J. N. Am. Benthol. Soc., $7: 433-455$.

Stretta E. 1950. - Hydrogéologie du flanc nord des Béni Snassen en amont de Berkane, Notes Mém. Ser. Géol. Maroc $n^{\circ} 74$. Tome 2 : 213-221. 